\title{
Copurification of Brain G-Protein $\beta 5$ with RGS6 and RGS7
}

\author{
Jian-Hua Zhang and William F. Simonds \\ Metabolic Diseases Branch, National Institute of Diabetes and Digestive and Kidney Diseases, National Institutes of \\ Health, Bethesda, Maryland 20892
}

\begin{abstract}
A structurally divergent G-protein $\beta$ subunit expressed in brain and retina, $\mathrm{G} \beta_{5}$, exhibits functional specialization in its proteinprotein interactions in vitro. In retina, $\mathrm{G} \beta 5$ has been isolated in a soluble complex with regulator of G-protein signaling RGS7. The function and molecular associations of $\mathrm{G} \beta_{5}$ in brain are unknown. To identify tightly bound proteins associated with $\mathrm{G} \beta_{5}$ in the brain, it was immunoaffinity-purified from a nonionic detergent extract of washed mouse brain membranes using an antibody directed against its $\mathrm{N}$ terminus. Elution with cognate peptide revealed a broad band of $55 \mathrm{kDa}$ that coeluted with $\mathrm{G} \beta_{5}$ on SDS-PAGE. The copurifying $55 \mathrm{kDa}$ band was identified as a $\sim 1: 1$ mixture of RGS6 and RGS7 by matrix-assisted laser
\end{abstract}

desorption ionization mass spectroscopic analysis of tryptic peptides. $\mathrm{G} \beta_{5}$ and RGS7 could be reciprocally coimmunoprecipitated from unfractionated brain membrane extracts confirming the tight association of native proteins. In contrast, immunoblotting of the peptide eluate revealed no copurifying $\mathrm{G} \alpha \mathrm{q} / 11, \mathrm{G} \alpha \mathrm{i} 1 / 2, \mathrm{G} \gamma 2, \mathrm{G} \gamma 3$, or $\mathrm{G} \gamma 7$. These findings implicate RGS6 and RGS7 in the function of $\mathrm{G} \beta_{5}$ in the brain and suggest that a large fraction of membrane-targeted $\mathrm{G} \beta_{5}$ has no associated $\mathrm{G} \gamma$ subunit and therefore functions outside the canonical framework of $\mathrm{G} \beta \gamma$ interactions.

Key words: signal transduction; G-proteins; regulators of G-protein signaling; Igs; affinity purification; mass spectroscopy
Heterotrimeric guanine-nucleotide-binding regulatory proteins (G-proteins) mediate signals generated after activation of seven transmembrane-spanning receptors in eukaryotic cells. The G $\beta \gamma$ complex of G-proteins may regulate effectors independently of the $\mathrm{G} \alpha$ subunits, so that after activation, G-proteins may signal downstream along one or both pathways (Clapham and Neer, 1997). The $G \beta_{5}$ isoform exhibits much less homology with the $\mathrm{G} \beta_{1-4}$ isoforms $(\sim 50 \%)$ and is preferentially expressed in neural tissue (Watson et al., 1994). A splice variant of $\mathrm{G} \beta_{5}, \mathrm{G} \beta_{5}$-long $\left(\mathrm{G} \beta_{5} \mathrm{~L}\right)$, has been identified in retina that contains a 42 amino acid N-terminal extension (Watson et al., 1996).

When analyzed in vitro the $\mathrm{G} \beta_{5}$ isoform exhibits a degree of selectivity in its protein-protein interactions previously unknown among $\mathrm{G} \beta$ subunits. Two categories of selective interaction have been documented for $\mathrm{G} \beta_{5}$ in vitro: $\mathrm{G} \gamma$-dependent interactions with conventional $\mathrm{G} \beta \gamma$ partners such as $\mathrm{G} \alpha$ subunits and $\mathrm{G} \beta \gamma$ responsive effectors (Zhang et al., 1996; Bayewitch et al., 1998; Fletcher et al., 1998; Lindorfer et al., 1998), and interactions with a subset of the regulator of G-protein signaling (RGS) proteins that appear to be G $\gamma$-independent (Snow et al., 1998, 1999; Levay et al., 1999; Makino et al., 1999).

The above in vitro findings leave open the important question of the functional associations of $\mathrm{G} \beta_{5}$ in brain. Cabrera et al. (1998) identified a native complex between G $\beta 5$ and RGS7 in a bovine retinal soluble fraction. However unlike in retina, where $G \beta_{5}$ is almost entirely soluble, the majority of $\mathrm{G} \beta_{5}$ in the brain is membrane-associated (Watson et al., 1996). In this respect, it resembles conventional $\mathrm{G} \beta \mathrm{s}$ in brain $\mathrm{G} \beta \gamma$ complexes that are

\footnotetext{
Received Oct. 19, 1999; revised Nov. 22, 1999; accepted Nov. 24, 1999.

The authors wish to thank Dr. Brian Cox of Borealis Biosciences for his expert help with the mass spectroscopy and Dr. Allen Spiegel for continuing support and encouragement. Correspondence should be addressed to Dr. William F. Simonds, National Institute of Diabetes and Digestive and Kidney Diseases, Metabolic Diseases Branch, Building 10, Room 8C-101, 10 Center Drive MSC 1752, Bethesda, MD 20892-1752. E-mail: wfs@helix.nih.gov.

Copyright (C) 2000 Society for Neuroscience $\quad 0270-6474 / 00 / 200001-\bullet \$ 15.00 / 0$
}

membrane-targeted by virtue of $\mathrm{G} \gamma$ subunit isoprenylation (Higgins and Casey, 1996). We describe here an approach to the purification $\mathrm{G} \beta_{5}$ from brain membranes, and under these experimental conditions, find no evidence of its association with several $\mathrm{G} \alpha$ or $\mathrm{G} \gamma$ subunits tested. Instead, brain membrane $\mathrm{G} \beta_{5}$ copurifies with the regulators of G-protein signaling, RGS6 and RGS7.

\section{MATERIALS AND METHODS}

Brain membrane preparation and detergent extraction. Whole brains were collected from adult female CD1 mice and stored in liquid nitrogen. For each preparation, $\sim 5 \mathrm{gm}$ of mouse brain was thawed, minced, and homogenized in $50 \mathrm{ml}$ of ice-cold homogenizing buffer on ice. Homogenization buffer consisted of $20 \mathrm{~mm} \mathrm{Na-HEPES,} \mathrm{pH} \mathrm{7.4,} 150 \mathrm{~mm} \mathrm{NaCl}$, $1 \mathrm{~mm} \beta$-mercaptoethanol, $3 \mathrm{~mm} \mathrm{MgCl}, 17 \mu \mathrm{g} / \mathrm{ml} \mathrm{4-(2-aminoethyl)-}$ benzenesulfonyl fluoride hydrochloride (AEBSF), $2 \mu \mathrm{g} / \mathrm{ml}$ of aprotinin, leupeptin, and pepstatin, and $1 \mu \mathrm{g} / \mathrm{ml}$ of soybean trypsin inhibitor. The homogenate was centrifuged at $1000 \times g$ for $15 \mathrm{~min}$ to remove cell debris and followed by a centrifugation at $100,000 \times g$ for $1 \mathrm{hr}$ to precipitate the membranes. The membrane pellet was washed twice by resuspension and recentrif ugation in homogenization buffer, then finally resuspended in 50 $\mathrm{ml}$ of solubilization buffer [homogenization buffer containing $0.2 \% \mathrm{w} / \mathrm{v}$ polyoxyethylene (10) monolauryl ether (Genapol C-100)] and stirred on ice for $2 \mathrm{hr}$. The detergent extract was centrifuged at $100,000 \times g$ for 1 $\mathrm{hr}$ to remove insoluble particulate. The supernatant detergent extract was used immediately for immunoaffinity purification as described below.

This article is published in The Journal of Neuroscience, Rapid Communications Section, which publishes brief, peerreviewed papers online, not in print. Rapid Communications are posted online approximately one month earlier than they would appear if printed. They are listed in the Table of Contents of the next open issue of JNeurosci. Cite this article as: JNeurosci, 2000, 20:RC59(1-5). The publication date is the date of posting online at www.jneurosci.org.

http://www.jneurosci.org/cgi/content/full/3895 
Affinity purification of Ggb5 N-terminal antibody. Crude polyclonal antiserum ATDG was generated in rabbits against the synthetic 16-mer peptide ATDGLHENETLASLKS-amide, corresponding to residues 2-17 at the $\mathrm{N}$ terminus of mouse $\beta_{5}$ (Watson et al., 1994). Immobilized peptide beads were prepared by coupling the peptide to $\mathrm{N}$-hydroxysuccinimideactivated agarose beads in $0.1 \mathrm{M}$ 4-morpholinepropanesulfonic acid, $\mathrm{pH} 7.5$ (Affi-Gel 15; Bio-Rad, Richmond, CA) and used to affinity purify antipeptide antibody (Harlow and Lane, 1988).

Preparation of the ATDG antibody affinity column. Two methods were used: (1) to prepare ATDG antibodies covalently crosslinked to Protein A, $12.3 \mathrm{mg}$ of Ig were crosslinked to $2 \mathrm{ml}$ of Protein A agarose by dimethylpimelimidate in sodium borate buffer, $\mathrm{pH} 8.2$ (Immunopure Protein A IgG Orientation kit; Pierce, Rockford, IL); (2) for noncovalent antibodyprotein A columns, affinity-purified Igs $(\sim 15 \mathrm{mg})$ from rabbit ATDG antiserum were mixed with $2 \mathrm{ml}$ of Protein A-coupled agarose beads pre-equilibrated with $500 \mathrm{~mm} \mathrm{NaCl} / 20 \mathrm{~mm}$ Tris-HCl, $\mathrm{pH} 7.5$, (TBS) and incubated by end-over-end rotation at $4^{\circ} \mathrm{C}$ for $2 \mathrm{hr}$. The mixture was then split in half and after settling of the agarose beads, and each $1 \mathrm{ml}$ column was equilibrated in solubilization buffer.

Affinity purification of the $G \beta 5$ complex and associated proteins. For an individual experiment, $50 \mathrm{ml}$ of mouse brain detergent extract, prepared as described above, was applied to a $1 \mathrm{ml}$ bed volume affinity column at the rate of $\sim 2 \mathrm{ml} / \mathrm{hr}$ using a peristaltic pump in a $4^{\circ} \mathrm{C}$ cold room. Weakly bound proteins were washed off of the column by pumping $250 \mathrm{ml}$ of the wash buffer [homogenization buffer containing $0.1 \%(\mathrm{w} / \mathrm{v})$ Genapol $\mathrm{C}-100]$ through the column at the same rate as for the sample loading. After the last $6 \mathrm{ml}$ of wash was examined by silver stain, the column was eluted with elution buffer [10 mM ATDG peptide in $0.1 \%$ (w/v) Genapol C-100; $20 \mathrm{~mm}$ Na-HEPES, $\mathrm{pH} 7.4,150 \mathrm{~mm} \mathrm{NaCl}, 1 \mathrm{~mm} \beta-$ mercaptoethanol, $3 \mathrm{~mm} \mathrm{MgCl} 2,17 \mu \mathrm{g} / \mathrm{ml}$ AEBSF, $2 \mu \mathrm{g} / \mathrm{ml}$ of aprotinin, leupeptin, and pepstatin, and $1 \mu \mathrm{g} / \mathrm{ml}$ of soybean trypsin inhibitor]. The elution was performed by loading $1.5 \mathrm{ml}$ of elution buffer onto the washed column and incubating for $24 \mathrm{hr}$ at $4^{\circ} \mathrm{C}$. The process was repeated until no detectable level of $\mathrm{G} \beta_{5}$ was present in the eluate ( 5-6 elution fractions).

Gel electrophoresis and immunoblotting. Protein samples were separated on $4-20 \%$ gradient slab gels by SDS-PAGE and transferred to nitrocellulose membranes for immunoblotting according to standard procedures (Harlow and Lane, 1988). The primary antibodies used for immunoblotting were rabbit SGS polyclonal (Zhang et al., 1996), rabbit antiserum AS/7 (Goldsmith et al., 1987), rabbit antiserum QL (Shenker et al., 1991), rabbit EDPL polyclonal (Lee et al., 1995), rabbit anti-G $\gamma_{7}$ S-14 Ig (Santa Cruz Biotechnology, Santa Cruz, CA) and goat anti-RGS7 C-19 Ig (Santa Cruz). Antibodies were added at the dilution of 1:500 unless otherwise specified and incubated at room temperature for 2-16 hr. The blots were washed twice at 15 min intervals in TBS containing $0.2 \%(\mathrm{w} / \mathrm{v})$ Tween 20. Secondary detection used [ ${ }^{125}$-I]Protein A (for rabbit antiserum) or [ ${ }^{125}$-I]Protein G (goat and other antiserum) followed by imaging on a storage phosphor screen. For visualization of protein bands, polyacrylamide gels were silver-stained and/or stained with Coomassie blue G250.

Identification of proteins associated with $G \beta 5$ protein. Aliquots of fractions collected off the affinity column with elution buffer were analyzed by SDS-PAGE and visualized by silver staining. Elution fractions containing the highest level of $\mathrm{G} \beta_{5}$ protein, as identified by Western blot analysis, were pooled and concentrated. The fractions were then separated by SDS-PAGE and visualized by staining with Coomassie blue G250. The broad band, whose elution profile paralleled that of the $G \beta_{5}$ protein band in several elution fractions, was chosen as a candidate for further identification. The band of interest was excised from the gel, and tryptic peptides were analyzed by matrix-assisted laser desorption/ionization-time of flight analysis (MALDI-ToF) (Borealis Biosciences Inc., Toronto, Ontario, Canada). Proteins were identified from the masses of the proteolytic peptides in the MALDI-ToF spectra by comparison with hypothetical proteolytic peptide masses derived from nonredundant translated genomic database using a Bayesian algorithm [ProFound version 3.2 software (Zhang and Chait, 1995)].

Immunoprecipitation. For each reaction, $1 \mathrm{ml}$ of the above membrane extract of mouse brain was mixed with anti-G $\beta_{5}$ or -RGS7 affinitypurified $\mathrm{IgG}$ or control $\mathrm{IgG}$ so that the final concentration of the $\mathrm{IgG}$ was $\sim 40 \mathrm{~nm}$ and incubated at $4^{\circ} \mathrm{C}$ overnight. Then Protein A/G Plus Agarose beads (Santa Cruz Biochemicals) $(15 \mu \mathrm{l})$ were added and incubated atroom temperature for $2 \mathrm{hr}$. At the end of incubation, the beads were pelleted by centrifugation at $10,000 \times g$ for 2 min and washed with $3 \times$ $200 \mu \mathrm{l}$ homogenization buffer described above. For specificity control reactions, blocking peptide (400 nM) were mixed with corresponding

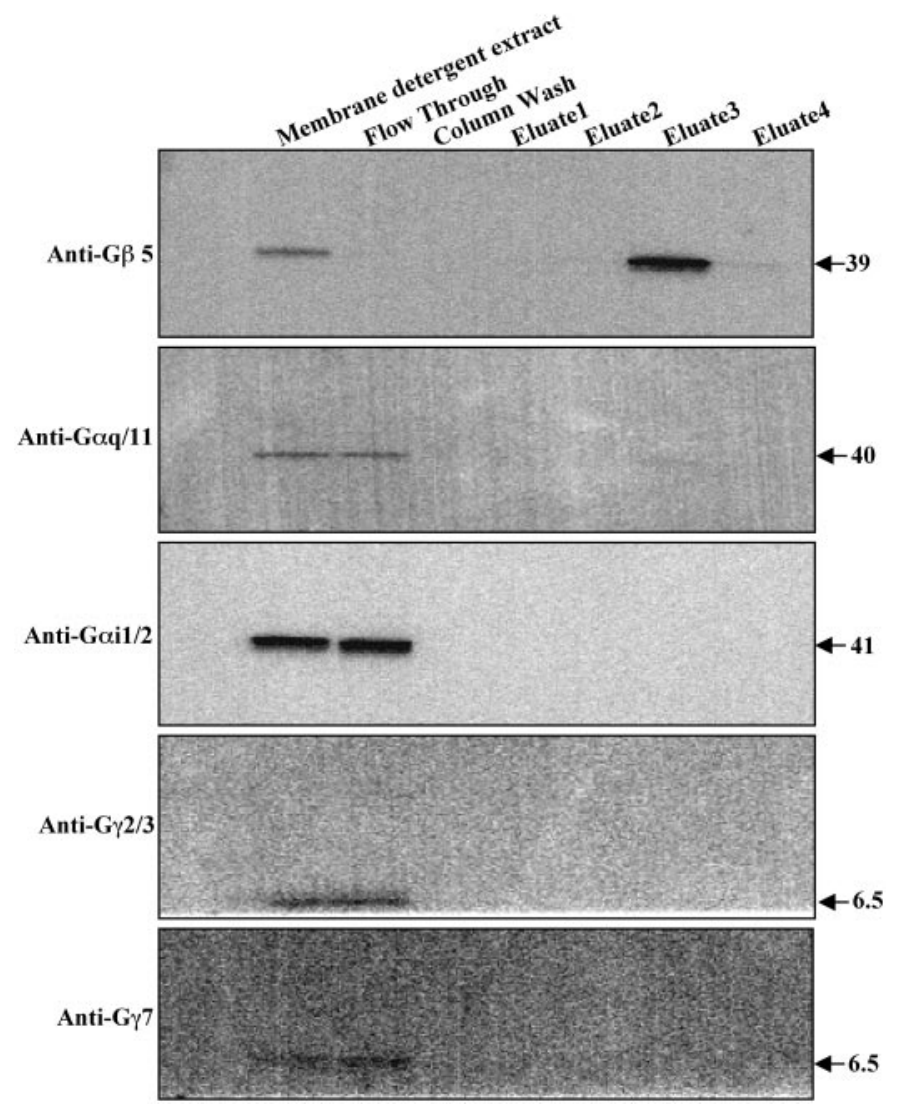

Figure 1. Analysis of G-protein subunits in mouse brain fractions by immunoblotting after anti-G $\beta_{5}$ immunoaffinity purification. Detergent extract from mouse brain was fractionated by passage over immobilized anti-G $\beta_{5}$ antibody and eluted with specific peptide, and the fractions were analyzed with antibodies to G-protein subunits, as described in Materials and Methods. The type of fraction is indicated above the lanes. In the left margin the antibody used in each immunoblot is indicated, and in the right margin the approximate $M_{\mathrm{r}}$ of the relevant immunoreactive band is indicated. The antibodies used include SGS against the $\mathrm{C}$ terminus of $\mathrm{G} \beta_{5}$ (Zhang et al., 1996) (Anti-G $\left.\beta_{5}\right)$, antibody QL against the $C$ terminus of G $\alpha \mathrm{q} / 11$ (Shenker et al., 1991) (Anti-G $\alpha \mathrm{q} / 11$ ), antiserum AS/7, which recognizes the $\mathrm{C}$ terminus of $\mathrm{G} \alpha_{\mathrm{i} 1}$ and $\mathrm{G} \alpha_{\mathrm{i} 2}$ (Goldsmith et al., 1987) $\left(\right.$ Anti-G $\alpha i_{1 / 2}$ ), polyclonal EDPL against the $\mathrm{C}$ terminus of $\mathrm{G} \gamma_{2}$ and $\mathrm{G} \gamma_{3}$ (Lee et al., 1995) (Anti-G $\left.\gamma_{2 / 3}\right)$, and rabbit anti-G $\gamma_{7} \operatorname{Ig~S}-14\left(\right.$ Anti-G $\left.\gamma_{7}\right)$. In membrane detergent extract, flow through, and column wash lanes, $0.04 \%$ of sample was analyzed per gel lane and, in eluate lanes, $1.3 \%$ of total. The results from one purification experiment are shown, representative of three such experiments.

antibodies before the antibodies were mixed with membrane extracts. The proteins bound on the beads were released by adding $100 \mu \mathrm{l}$ of $1 \times$ denaturing sample loading buffer and vortexing for $5 \mathrm{sec}$. Proteins were separated by SDS-PAGE and detected by Western blot analysis as described above.

\section{RESULTS}

\section{Purification of $\mathbf{G} \beta_{5}$ from mouse brain membranes}

The concentration of $\mathrm{G} \beta_{5}$ in unfractionated mouse brain was estimated to be $\sim 0.25 \%$ of total brain proteins by quantitative comparison of brain homogenates with a range of concentrations of highly purified recombinant $\mathrm{G} \beta_{5} \mathrm{~L}$ on immunoblots developed with C-terminally directed $\mathrm{G} \beta_{5}$ antibody SGS (Zhang et al., 1996) and $\left[{ }^{125}-\mathrm{I}\right]$ Protein $A$ (data not shown). Of this total $G \beta_{5}$ in mouse brain, $60 \%$ was membrane-associated and $40 \%$ was soluble (data not shown). This was in fair agreement with the findings of 

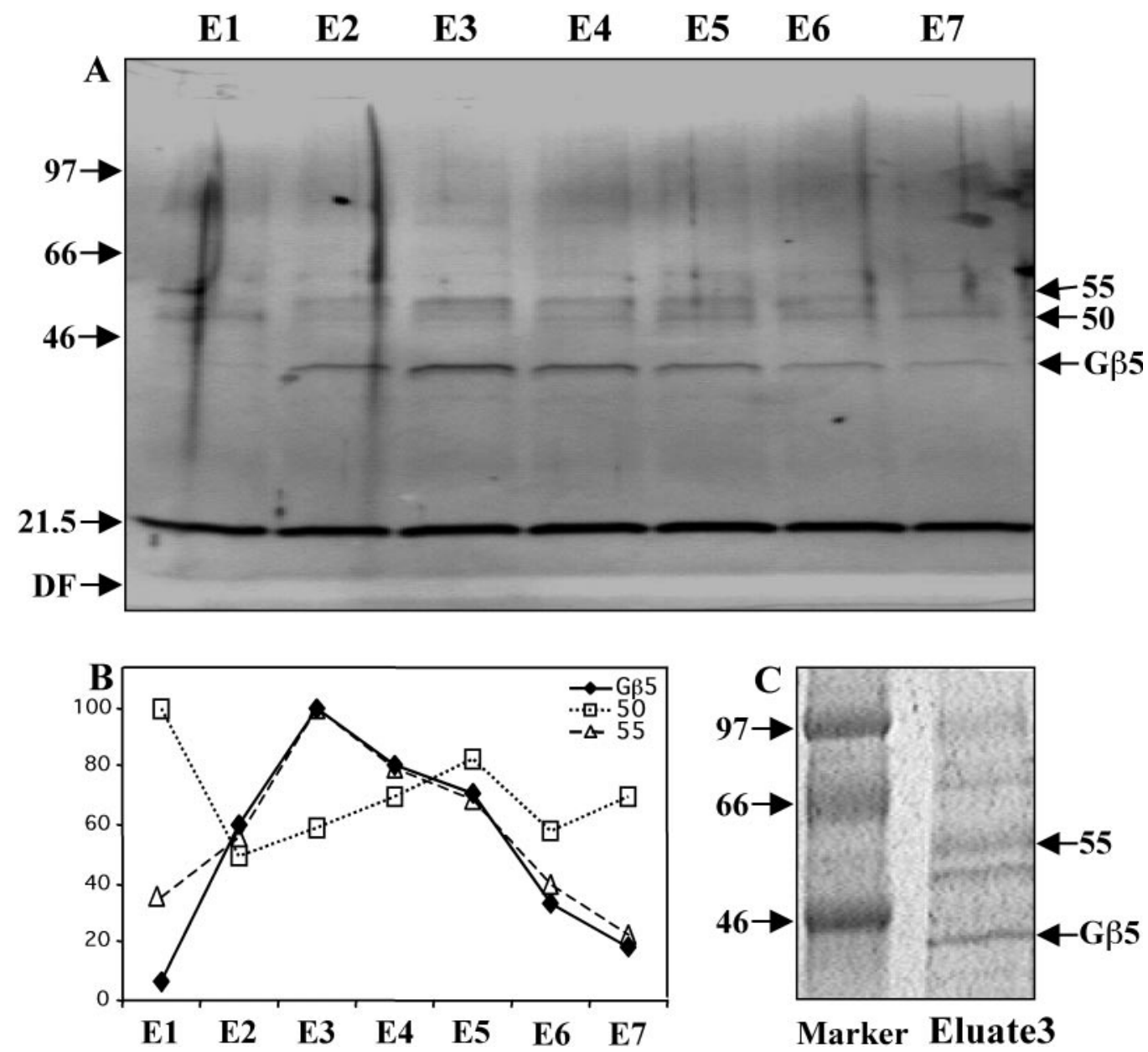

Watson et al. (1996), who found $70 \%$ of the $\mathrm{G} \beta_{5}$ in brain to be in the membrane pellet.

We chose the membrane fraction as a starting material for purification of $\mathrm{G} \beta_{5}$ from mouse brain. Because other $\mathrm{G} \beta$ subunits in brain are membrane anchored through tight association with $\mathrm{G} \gamma$ subunits that are post-translationally lipid-modified by isoprenylation (Higgins and Casey, 1996), it was considered most likely that any $\mathrm{G} \beta_{5}-\mathrm{G} \gamma$ complexes in brain would be similarly expressed in the membrane fraction. Studies on purified recombinant $\mathrm{G} \beta_{5}-$ $\mathrm{G} \gamma_{2}$ complexes demonstrated an unusual sensitivity of $\mathrm{G} \beta_{5}-\mathrm{G} \gamma_{2}$ interaction to bile salt-related detergents such as cholate and 3-[(3cholamidopropyl)dimethylammonio]-1-propanesulfonic acid (Jones and Garrison, 1999). For this reason, brain membranes were extracted with the polyoxyethylene (10) monolauryl ether, Genapol C-100. Nonionic detergents of this type were found to be compatible with $\mathrm{G} \beta_{5}-\mathrm{G} \gamma_{2}$ association in vitro (Jones and Garrison, 1999).

Detergent extraction and column-wise immunoaffinity purification of $\mathrm{G} \beta_{5}$ from brain membranes yielded $\sim 30 \mu \mathrm{g}$ of $\mathrm{G} \beta_{5}$ from $100 \mathrm{mg}$ of protein in the starting brain membranes. The $\mathrm{G} \beta_{5}$ after this step ranged from $\sim 10$ to $30 \%$ pure, a degree of purity sufficient to allow clear resolution of $\mathrm{G} \beta_{5}$ at $39 \mathrm{kDa}$ from other discrete protein bands by silver and Coomassie blue staining after SDS-PAGE (Fig. 2A).

Analysis of the flow through and eluate from the antibody column by immunoblotting documented the efficient capture of $\mathrm{G} \beta_{5}$ from the detergent extract and its release by the cognate
Marker Eluate3
Figure 2. Coelution of a $55 \mathrm{kDa}$ protein band with $\mathrm{G} \beta_{5}$. A, Consecutive peptide-eluted fractions (E1E7) from the anti-G $\beta_{5}$ antibody column were analyzed by silver staining after separation by SDSPAGE. Shown in the left margin are the relative mobilities of marker proteins (in kilodaltons) run in an adjacent lane (data not shown), and the position of the dye front $(D F)$. Visible at $21.5 \mathrm{kDa}$ in all lanes is soybean trypsin inhibitor included in the elution buffer. In the right margin is indicated the position of $\mathrm{G} \beta_{5}$ at $39 \mathrm{kDa}$ and the $55 \mathrm{kDa}$ and $50 \mathrm{kDa}$ bands as described in Results. $B$, Plot of the relative staining intensities of $\mathrm{G} \beta_{5}$ at $39 \mathrm{kDa}$ (filled diamonds), the 55 $\mathrm{kDa}$ band (open triangles), and the $50 \mathrm{kDa}$ band (open squares) determined by densitometric analysis of the silver-stained gel shown in $A$. $C$, Preparative 4-20\% SDS-PAGE gradient gel stained by Coomassie blue containing a concentrate of fraction E3 (Eluate 3). The mobility of marker proteins (in kilodaltons) in an adjacent lane, and the position of $\mathrm{G} \beta_{5}$ at $39 \mathrm{kDa}$ and the broad band at $55 \mathrm{kDa}$, which was excised for MALDI-ToF analysis, are indicated. peptide (Fig. 1). Of the total $\mathrm{G} \beta_{5}$ in the detergent extract applied to the antibody column, virtually all was retained, and $\sim 25 \%$ could be recovered in the peptide eluate. Despite the concentration of $\mathrm{G} \beta_{5}$ by the antibody column, immunoblotting with antisera to several $\mathrm{G} \alpha$ and $\mathrm{G} \gamma$ subunits revealed no coelution with $\mathrm{G} \beta_{5}$ under these conditions (Fig. 1). Notably absent in the eluate were $\mathrm{G} \alpha \mathrm{q}$ and $\mathrm{G} \gamma_{2}$, G-protein subunits shown in vitro to interact with $\mathrm{G} \beta_{5}$ (Fletcher et al., 1998).

Proteins bound to the antibody column were eluted stepwise in the cold with aliquots of $10 \mathrm{~mm}$ peptide solution, and the resulting proteins were analyzed by staining after SDS-PAGE (Fig. 2). Several protein bands were seen whose elution profile bore no relation to the band at $39 \mathrm{kDa}$ identified as $\mathrm{G} \beta_{5}$ by immunoblotting. One such band of $50 \mathrm{kDa}$ was evident in silver-stained gels of the eluate fractions and peaked two fractions later than the $\mathrm{G} \beta_{5}$ band (at $39 \mathrm{kDa}$ ) (Fig. $2 A, B$ ). Other bands of slower mobility, which also bore no evident relation to the elution profile of $\mathrm{G} \beta_{5}$, were seen in preparative gels stained with Coomassie blue (Fig. $2 C$ ). Because of their lack of correlation with the elution of $\mathrm{G} \beta_{5}$, such bands were considered likely to represent nonspecifically bound proteins. A diffuse protein band at $\sim 55 \mathrm{kDa}$ was reproducibly found to elute in parallel to the $\mathrm{G} \beta_{5}$ at 39 kDa (Fig. 2A,B). The corresponding fractions of eluate were concentrated and run on a preparative SDS-PAGE, and the broad band at $55 \mathrm{kDa}$ was excised from the gel for further analysis (Fig. 2C). 
Figure 3. Coverage plots mapping tryptic peptides identified by mass spectroscopy from the $55 \mathrm{kDa}$ protein band to the primary sequence of RGS6 and RGS7. $A$, The primary sequence of murine RGS6 is indicated by the top rectangle that is filled in black in positions corresponding to peptides identified by MALDI-ToF mass spectroscopic analysis, as described in Materials and Methods. The mass [and corresponding sequence (He et al., 1998) (GenBank accession number AF061933)] of the tryptic peptides identified include: 987.73 (K127-R134), 1134.77 (F302-K310), 1235.10 (S381-K391), 1317.89 (Q201R211), 1446.32 (K200-R211), 1457.25 (F290-R301), 1506.69 (L83-R95), 1543.37 (Y357-K368), 1733.56 (A81-R95), 1755.45 (K103-K116), 1771.60 (I128R141), 1797.22 (W270-R284), 1857.21 (Q201-K215), 1928.95 (D353-K368), 2500.98 (A135-R155), 2525.76 (S169-R191), 2654.45 (S169-K192), 2654.45 (K168$\mathrm{R} 191)$, and 3730.85 (R320-K352). B, The primary sequence of murine RGS7 is indicated by the top rectangle that is filled in black in positions corresponding to peptides identified by MALDI-ToF mass spectroscopic analysis, as described in Materials and Methods. The mass [and corresponding sequence (He et al.,

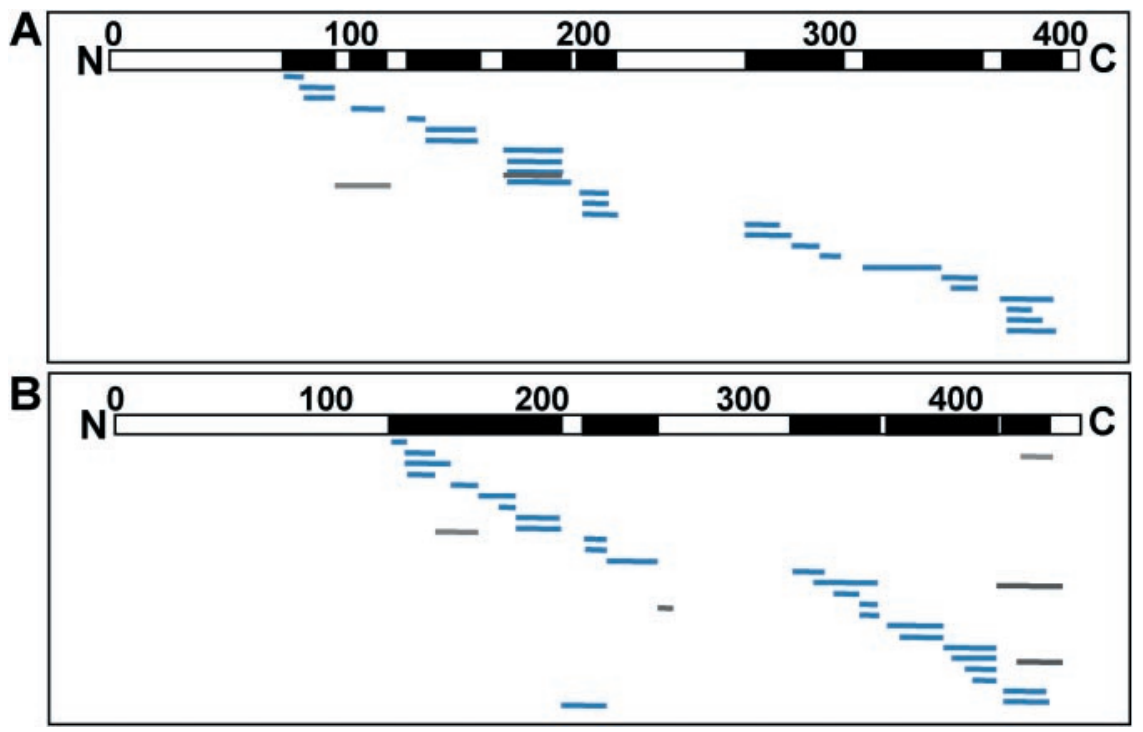
1998) (GenBank accession number AF011360)] of the tryptic peptides identified include: 987.73 (K187-R194), 1120.71 (Y264-R271), 1120.71 (F362-K370), 1163.92 (S229-R238), 1276.14 (F362-R371), 1292.57 (K228 -R238), 1457.25 (F350-R361), 1479.44 (L143-R155), 1543.37 (Y417-K428), 1677.80 (W330-R344), 1706.63 (A141-R155), 1726.67 (K163-K176), 1771.60 (I188-R201), 1983.23 (E413-K428), 2413.91 (V381-K402), 2440.80 (A195K215), 2836.19 (S239-K263), and 2983.13 (E376-K402).

\section{Identification of the $55 \mathrm{kDa}$ protein band co-eluting with $\mathrm{G} \beta 5$ as a mixture of RGS6 and RGS7}

The $55 \mathrm{kDa}$ protein band excised from the gel was trypsinized overnight, and the resulting tryptic peptides were subjected to MALDI-ToF mass spectroscopy. The masses of the proteolytic peptides in the MALDI-ToF spectra were compared with theoretical proteolytic peptide masses derived from the nonredundant translated genomic database using a Bayesian algorithm (Zhang and Chait, 1995) to allow identification of the component proteins. Peptides were identified that covered $>50 \%$ each of the primary sequence of two proteins in the database, allowing identification of murine regulators of G-protein signaling RGS6 and RGS7 (Fig. 3). Within the $55 \mathrm{kDa}$ protein band, assuming no sequence-specific bias in the recovery of peptides, the MALDIToF analysis of the recovered tryptic peptides suggested the two RGS proteins were present in approximately equimolar amounts.

\section{Reciprocal coimmunoprecipitation of $\mathrm{G}_{5}$ and RGS7 in unfractionated brain extract}

To verify the presence of native complexes of $\mathrm{G} \beta_{5}$ and RGS7 in brain membranes, aliquots of an unfractionated detergent extract of mouse brain membranes were separately immunoprecipitated with antibodies to $\mathrm{G} \beta_{5}$ and RGS7 in the absence and presence of blocking peptide, or with control antibodies (Fig. 4). Comparable experiments with anti-RGS6 were not performed because of the lack of published or commercial sources for such an antibody. Immunoblots of the washed immunoprecipitates revealed the presence of both $\mathrm{G} \beta_{5}$ and RGS7 in the anti-G $\beta_{5}$ pellets, and both were eliminated by the inclusion of specific blocking peptide (Fig. $4 A, B)$. Similarly, both $\mathrm{G} \beta_{5}$ and RGS7 were present in the pellets of anti-RGS7 precipitates, and both were eliminated by the inclusion of the cognate RGS7 peptide (Fig. $4 C, D$ ). Neither $\mathrm{G} \beta_{5}$ nor RGS7 were present in immunoprecipitates using control rabbit or goat antibodies. Furthermore, immunoblot analysis of the same column fractions shown in Figure 1 with anti-RGS7 antibody demonstrated a concentration of RGS7 in the peak eluate fraction paralleling $\mathrm{G} \beta_{5}$ (data not shown).
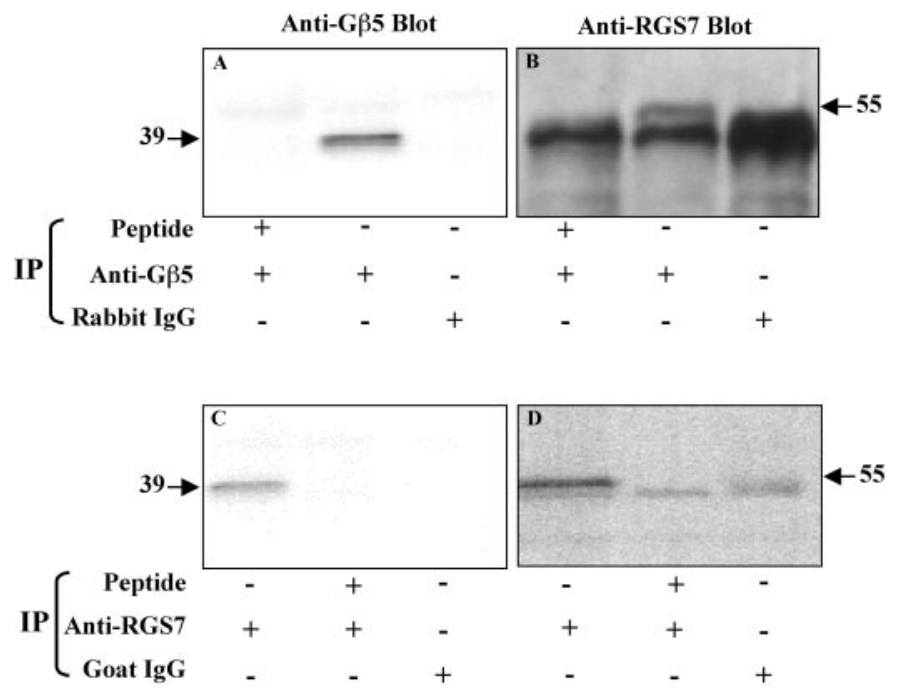

Figure 4. Reciprocal coimmunoprecipitation of G-protein $\beta_{5}$ and RGS7 from unfractionated mouse brain extract. Aliquots of a Genapol C-100 detergent extract of whole mouse brain were immunoprecipitated (IP) with the indicated antibodies without or with an excess of antigenic peptide as shown, as described in Materials and Methods. Immunoblots with anti-G $\beta_{5} \mathrm{C}$-terminal antibody SGS $(A, C)$ or anti-RGS7 C-terminal antibody $(B, D)$ are shown, with the $M_{\mathrm{r}}$ of $\mathrm{G} \beta_{5}(39 \mathrm{kDa})$ and RGS7 (55 $\mathrm{kDa}$ ) indicated in the margins. Nonspecific bands at $\sim 50 \mathrm{kDa}$ in $B$ and $D$ correspond to the heavy chain of IgG. $A, B$, Immunoprecipitation with affinity-purified anti-G $\beta_{5}$ antibody ATDG or control rabbit IgG. $C, D$, Immunoprecipitation with anti-RGS7 IgG or control goat IgG.

\section{DISCUSSION}

Using an antibody-based purification scheme, native complexes of G $\beta_{5}$ with RGS6 and RGS7 were isolated from mouse brain membranes. This is in line with the previous findings in retina in which native complexes between $\mathrm{G} \beta_{5}$ and RGS7 in the soluble fraction (Cabrera et al., 1998) and $G \beta_{5} L$ and RGS9 in the membrane fraction of rod outer segments (Makino et al., 1999) were identified. Mammalian RGS proteins 6, 7, 9, and 11 com- 
prise a subset of the RGS proteins that contain a $\mathrm{G} \gamma$-like domain that confers binding to $\mathrm{G} \beta_{5}$ and $\mathrm{G} \beta_{5} \mathrm{~L}$ (Snow et al., 1998, 1999; Levay et al., 1999). This subset of RGS proteins shares a similar modular organization: an N-terminal dishevelled-Egl-10-pleckstrin (DEP) homology domain (Ponting and Bork, 1996) of unknown function, followed by a $\mathrm{G} \gamma$-like domain, and finally the core RGS homology domain near the $\mathrm{C}$ terminus, known to function as a GTPase-activating protein (GAP) for heterotrimeric $\mathrm{G} \alpha$ subunits (Berman and Gilman, 1998). Because $G \beta_{5}$ and $G \beta_{5} L$ appear to bind RGS proteins of this subfamily in 1:1 complexes to the exclusion of a G $\gamma$ subunit (Levay et al., 1999; Makino et al., 1999), we presume that what we have isolated from brain represents a mixture of $\mathrm{G} \beta_{5}$-RGS6 and $\mathrm{G} \beta_{5}$-RGS7 complexes. We cannot rule out the presence of free $\mathrm{G} \beta_{5}$ in our isolate as well.

This is the first report in which RGS6 has been identified in a native protein complex. Expression of RGS6 mRNA has been documented by in situ hybridization in brain (Gold et al., 1997) and by Northern analysis in brain and heart (Snow et al., 1999). RGS6 and RGS7 are the most homologous pair (74\% identical residues) among the four mammalian RGS proteins so far identified with DEP and G $\gamma$-like domains (Snow et al., 1999). The basis for membrane attachment of complexes of $\mathrm{G} \beta_{5}$ with RGS6 and RGS7 in brain remains obscure.

Although this purification scheme yielded $\sim 25 \%$ of the $G \beta_{5}$ from brain membranes, no associated $\mathrm{G} \gamma$ subunits could be detected in an immunological screen for several G $\gamma$ subunits known to be neurally expressed. We cannot, of course, exclude the presence of other $\mathrm{G} \gamma$ subunits outside of our screen, or low levels of $\mathrm{G} \gamma$ below the limit of our detection method. The nonionic detergent used here was chosen based on its compatibility with $\mathrm{G} \beta_{5}-\mathrm{G} \gamma$ complex formation in vitro (Jones and Garrison, 1999). Nevertheless, associated $\mathrm{G} \gamma$ subunits may still have been lost during the relatively slow purification process described here, a methodology that may have favored isolation of high-affinity $\mathrm{G} \beta_{5}$-RGS complexes. Even if $\mathrm{G} \beta_{5}$ in brain was directly immunoprecipitated from detergent solution with the N-terminal antibody however, in place of the slower column-wise purification, no associated $\mathrm{G} \gamma$ subunits were detectable in blots of the immunoprecipitates (data not shown). Similarly, it is also possible the $\mathrm{N}$-terminally directed anti-G $\beta_{5}$ antibody selected against $\mathrm{G} \beta_{5}-\mathrm{G} \gamma$ complexes or actually promoted dissociation of $\mathrm{G} \gamma$ from $\mathrm{G} \beta_{5}$. Because $\mathrm{G} \beta_{5}-\mathrm{G} \gamma$ complexes have been shown in vitro to possess many functional properties expected of G $\beta \gamma$ (Zhang et al., 1996; Bayewitch et al., 1998; Fletcher et al., 1998; Lindorfer et al., 1998), an important remaining question is whether $\mathrm{G} \beta_{5}-\mathrm{G} \gamma$ complexes may exist transiently or constitutively within intact developing or adult neurons.

The present findings nevertheless suggest that in adult brain a large fraction of $\mathrm{G} \beta_{5}$ functions without an associated $\mathrm{G} \gamma$ subunit and therefore outside the classical conceptual framework of $\mathrm{G} \beta \gamma$ interactions. The extent to which $\mathrm{G} \beta_{5}-\mathrm{RGS}$ complexes may function in a fashion analogous to $\mathrm{G} \beta \gamma$ complexes is unknown. Similarly obscure is the role of the DEP domain and how the juxtaposition of an RGS core domain and $\mathrm{G} \beta_{5}$ within such complexes may mutually influence their protein-protein interactions. Answering the myriad questions raised by the discovery of $\mathrm{G}_{5}-$ RGS protein complexes will undoubtedly require future insights from many lines of experimental inquiry.

\section{REFERENCES}

Bayewitch ML, Avidor-Reiss T, Levy R, Pfeuffer T, Nevo I, Simonds WF, Vogel Z (1998) Differential modulation of adenylyl cyclases I and II by various $\mathrm{G}_{\beta}$ subunits. J Biol Chem 273:2273-2276.

Berman DM, Gilman AG (1998) Mammalian RGS proteins: barbarians at the gate. J Biol Chem 273:1269-1272.

Cabrera JL, De Freitas F, Satpaev DK, Slepak VZ (1998) Identification of the G $\beta 5$-RGS7 protein complex in the retina. Biochem Biophys Res Commun 249:898-902.

Clapham DE, Neer EJ (1997) G protein $\beta \gamma$ subunits. Annu Rev Pharmacol Toxicol 37:167-203.

Fletcher JE, Lindorfer MA, DeFilippo JM, Yasuda H, Guilmard M, Garrison JC (1998) The G protein $\beta_{5}$ subunit interacts selectively with the $\mathrm{G}_{\mathrm{q}} \alpha$ subunit. J Biol Chem 273:636-644.

Gold SJ, Ni YG, Dohlman HG, Nestler EJ (1997) Regulators of G-protein signaling (RGS) proteins: region-specific expression of nine subtypes in rat brain. J Neurosci 17:8024-8037.

Goldsmith P, Gierschik P, Milligan G, Unson CG, Vinitsky R, Malech HL, Spiegel AM (1987) Antibodies directed against synthetic peptides distinguish between GTP-binding proteins in neutrophil and brain. J Biol Chem 262:14683-14688.

Harlow E, Lane D (1988) Antibodies: a laboratory manual. Cold Spring Harbor, NY: Cold Spring Harbor Laboratory.

He W, Cowan CW, Wensel TG (1998) RGS9, a GTPase accelerator for phototransduction. Neuron 20:95-102.

Higgins JB, Casey PJ (1996) The role of prenylation in G-protein assembly and function. Cell Signal 8:433-437.

Jones MB, Garrison JC (1999) Instability of the G-protein $\beta_{5}$ Subunit in detergent. Anal Biochem 268:126-133.

Lee C, Murakami T, Simonds WF (1995) Identification of a discrete region of the $\mathrm{G}$ protein gamma subunit conferring selectivity in $\beta \mathrm{gam}$ ma complex formation. J Biol Chem 270:8779-8784.

Levay K, Cabrera JL, Satpaev DK, Slepak VZ (1999) G $\beta 5$ prevents the RGS7-G $\alpha$ o interaction through binding to a distinct Ggamma-like domain found in RGS7 and other RGS proteins. Proc Natl Acad Sci USA 96:2503-2507.

Lindorfer MA, Myung CS, Savino Y, Yasuda H, Khazan R, Garrison JC (1998) Differential activity of the G protein $\beta 5 \gamma 2$ subunit at receptors and effectors. J Biol Chem 273:34429-34436.

Makino ER, Handy JW, Li TS, Arshavsky VY (1999) The GTPase activating factor for transducin in rod photoreceptors is the complex between RGS9 and type 5 G protein $\beta$ subunit. Proc Natl Acad Sci USA 96:1947-1952.

Ponting CP, Bork P (1996) Pleckstrin's repeat performance: a novel domain in G-protein signaling? Trends Biochem Sci 21:245-246.

Shenker A, Goldsmith P, Unson CG, Spiegel AM (1991) The G protein coupled to the thromboxane $\mathrm{A}_{2}$ receptor in human platelets is a member of the novel $\mathrm{G}_{\mathrm{q}}$ family. J Biol Chem 266:9309-9313.

Snow BE, Krumins AM, Brothers GM, Lee SF, Wall MA, Chung S, Mangion J, Arya S, Gilman AG, Siderovski DP (1998) A G protein gamma subunit-like domain shared between RGS11 and other RGS proteins specifies binding to $\mathrm{G}_{\beta 5}$ subunits. Proc Natl Acad Sci USA 95:13307-13312.

Snow BE, Betts L, Mangion J, Sondek J, Siderovski DP (1999) Fidelity of $\mathrm{G}$ protein $\beta$-subunit association by the $\mathrm{G}$ protein gamma-subunit-like domains of RGS6, RGS7, and RGS11. Proc Natl Acad Sci USA 96:6489-6494.

Watson AJ, Katz A, Simon MI (1994) A fifth member of the mammalian G-protein $\beta$-subunit family. Expression in brain and activation of the $\beta 2$ isotype of phospholipase C. J Biol Chem 269:22150-22156.

Watson AJ, Aragay AM, Slepak VZ, Simon MI (1996) A novel form of the $\mathrm{G}$ protein $\beta$ subunit $\mathrm{G} \beta_{5}$ is specifically expressed in the vertebrate retina. J Biol Chem 271:28154-28160.

Zhang SY, Coso OA, Lee CH, Gutkind JS, Simonds WF (1996) Selective activation of effector pathways by brain-specific $\mathrm{G}$ protein $\beta_{5}$. J Biol Chem 271:-32768.

Zhang W, Chait BT (1995) Protein identification by database searching: a Bayesian algorithm. Proceedings of the 43rd ASMS Conference on Mass Spectrometry and Allied Topics, May, 1995, Atlanta, GA, Abstract. 